\section{Anaerobic Incubation of Soil and the Production of Ammonium}

IN 1964 Waring and Bremner ${ }^{1}$ proposed a simple and attractive laboratory method for measuring an index to potentially available mineral nitrogen in the soil under anaerobic conditions of incubation; the original method has been compared with the aerobic incubation procedure of Bremner².

Anaerobic topsoil values $\left(\Delta \mathrm{NH}_{4}-\mathrm{N}\right)$ and aerobic topsoil values $\left(\Delta\left(\mathrm{NH}_{4}+\mathrm{NO}_{3}+\mathrm{NO}_{2}\right)-\mathrm{N}\right)$ were correlated with maize fertilizer experimental data obtained from a small number of trials (twenty sites) carried out in western Tanzania. The air dry topsoils $(0-15 \mathrm{~cm})$ used in the incubation tests were pretreated to overcome differences in methods of air drying and storage times and were crushed to pass a $2 \mathrm{~mm}$ round hole sieve. The comparative correlation coefficients between either one of the incubation values and soil organic carbon, Kjeldahlnitrogen in the soil, basic leaf nitrogen, leaf nitrogen increment with nitrogen fertilizer applications, basic crop yield and yield increment with nitrogen fertilizer application, are shown in Table 1. Also included is the correlation coefficient between the anaerobic and the aerobic incubation methods.

Table 1. CORRELATION COEFTTCIENTS FOR ANAEROBIC OR AFROBIC $\triangle$ MINERAL - V VALUES FOR TOPSOILS WITH THE SOIL ANALYSES AND DATA FROM MAIZE TRIALS IN THE FIELD

\begin{tabular}{|c|c|c|}
\hline $\begin{array}{l}\text { Parameters correlated with } \\
\text { inorganic }-\mathrm{N} \text { values }\end{array}$ & $\begin{array}{l}\text { Anaerobic soil } \\
\text { ineubation } \\
\Delta \mathrm{NH}_{4}-\mathrm{N}\end{array}$ & $\begin{array}{c}\text { Aerobic soil } \\
\text { incubation } \\
\Delta\left(\mathrm{NH}_{4}+\mathrm{NO}_{3}+\mathrm{NO}_{2}\right)-\mathrm{N}\end{array}$ \\
\hline $\begin{array}{l}\text { Organic carbon in the solls } \\
\text { Kjeldahl nitrogen in the soils } \\
\text { Maize leaf }-N \text { per cent (untreated }\end{array}$ & $\begin{array}{l}+0.561^{*} \\
+0.531^{*} \\
+0.170^{*} \text { N.S. }\end{array}$ & $\begin{array}{l}+0.597^{* *} \\
+0.659^{* *} \\
+0.614^{* *}\end{array}$ \\
\hline $\begin{array}{l}\text { control) } \\
\text { Maize leaf }-\mathrm{N} \text { per cent } \mathrm{N}_{2} \text { fertilizer } \\
\text { treatment }\end{array}$ & $-0 \cdot 480^{*}$ & -0.443 N.S. \\
\hline $\begin{array}{c}\Delta \text { Maize leaf }-N \text { per cent } N_{2} \text { fertilizer } \\
\text { treatment }\end{array}$ & r -0.343 N.S. & $-0.502^{*}$ \\
\hline $\begin{array}{l}\text { Maize yield lb./acre (untreated con- } \\
\text { trol) }\end{array}$ & $+0 \cdot 254$ N.S. & $+0.537^{*}$ \\
\hline$\underset{\text { treatment }}{\Delta \text { Maize yield lb./acre } \mathrm{N}_{2} \text { fertilizer }}$ & $r-0.510^{*}$ & $-0 \cdot 630^{* *}$ \\
\hline $\begin{array}{c}\text { AMaize yield lb./acre } \mathrm{N}, \text { fertilizer } \\
\text { treatment }\end{array}$ & $\mathbf{r}-0.530^{*}$ & $-0 \cdot 642^{* *}$ \\
\hline Anaerobic and aerobic soil incubation & & +0.374 N.S. \\
\hline \multicolumn{3}{|c|}{$\begin{array}{l}\text { All correlation coefficients have } 18 \text { degrees of freedom. } \\
* \text { **= Statistical signiflcance at the } 5 \text {, I per cent probability levels. } \\
\text { Soll organic carbon as uncorrected Walkley-Black values. } \\
\text { Soil data expressed on an oven dry soll weight basis; leaf data on an oven } \\
\text { dry matter weight basis. }\end{array}$} \\
\hline
\end{tabular}

It is apparent that the aerobic index is more satisfactory than the anaerobic index for determining potentially available mineral nitrogen in the soils.

A complicating factor in the anaerobic incubation test could be the presence of $\mathrm{NO}_{3}-\mathrm{N}$ (and $\mathrm{NO}_{2}-\mathrm{N}$, though normally it is present in relatively small quantities in well drained soil types) in the soil before the incubation. During the anaerobic incubation test $\mathrm{NO}_{3}-\mathrm{N}$ might be reduced to $\mathrm{NH}_{4}-\mathrm{N}$ (ref. 3) and would then be included as a part of the $\Delta \mathrm{NH}_{4}-\mathrm{N}$.

The fate of $\mathrm{NO}_{3}-\mathrm{N}$ present in soils at the beginning of the anaerobic incubation was investigated in terms of $\Delta \mathrm{NH}_{4}-\mathrm{N}$ found. $\mathrm{NH}_{4}-\mathrm{N}$ has been determined by the method described for the test ${ }^{1}$ and in the filtered extract was prepared with 2 normal potassium chloride at a ratio of $1: 5$ and $1: 10$ soil to extracting solution. One such experiment was made using $0-15 \mathrm{~cm}$ topsoil samples of a humic ferrisol ${ }^{5}$ ( $W-B$ carbon value, uncorrected $=$ 5.34), a ferrisol ${ }^{5}(W-B$ carbon value, uncorrected $=$ 2.72) and a ferralitic soil ${ }^{5}(W-B$ carbon value, uncorrected $=1 \cdot 65$ ). These soils were selected because they are all tropical red earths in the broadest sense but contained different amounts of organic matter; they also contained appreciable quantities of $\mathrm{NO}_{3}-\mathrm{N}$ before anaerobic incubation, particularly the humic ferrisol. Furthermore, subsamples were examined plus and minus the addition of $\mathrm{NO}_{3}-\mathrm{N}$ solution to the soil at a rate equivalent to 5 p.p.m. $\mathrm{NO}_{3}-\mathrm{N}$ in the oven dry sample, just before incubation. The experimental coefficient of variation was 3 per cent.
Table 2. $\triangle \mathrm{NH}_{4}-\mathrm{N}$ AFTER ANAEROBIC INCUBATION OB THREB SOLS ADDITTON OF $\mathrm{NO}_{3}-$ N (P.P.M. IN OVEN DRY SOLL)

$\begin{array}{llc}\quad \text { Soil type } & +\mathrm{NO}_{2}-\mathrm{N} & -\mathrm{NO}_{8}-\mathrm{N} \\ \text { Humic ferrisol } & 99 \cdot 9(4) & 94.5 \\ \text { Ferrisol } & 46 \cdot 9 & 47.1 \\ \text { Ferralitic soil } & 42.8 & 48.8 \\ \quad \text { Mean } & 63.2(12) & 61.7\end{array}$

Interaction L.S.D. $=2.9$ significant at $P=0.05$.

Figures in parentheses indicate the number of values in the mean.

A higher $\Delta \mathrm{NH}_{4}-\mathrm{N}$ value was found for the humic ferrisol in the presence of added $\mathrm{NO}_{3}-\mathrm{N}$ suggesting some slight reduction of $\mathrm{NO}_{3}-\mathrm{N}$ to $\mathrm{NH}_{4}-\mathrm{N}$ during anaerobic incubation in a soil containing a high level of organic matter.

However, a much greater discrepancy was observed for the $\Delta \mathrm{NH}_{\mathrm{s}}-\mathrm{N}$ values obtained by steam distilling the soil + extract as against the filtered extract only.

Table 3. THE EFFECW OF SOL PRESENT DURING STEAM DISTILLATION WITH Mgo ON $\triangle \mathrm{NH}_{4}-\mathrm{N}$ (P.P.M. IN OVEN DRY SOIL)

\begin{tabular}{|c|c|c|c|}
\hline \multicolumn{4}{|c|}{ Method } \\
\hline Soil type & $\underset{\text { extract }}{\text { Soil }}$ & $\begin{array}{l}\text { Filtered } \\
\text { extract }\end{array}$ & Mean \\
\hline $\begin{array}{l}\text { Humic ferrisol } \\
\text { Ferrisol } \\
\text { Ferralitic soil } \\
\quad \text { Mean }\end{array}$ & $\begin{array}{l}132 \cdot 0(4) \\
50 \cdot 7 \\
44 \cdot 5 \\
75 \cdot 5(12)\end{array}$ & $\begin{array}{c}62 \cdot 4 \\
43 \cdot 4 \\
41 \cdot 6 \\
49 \cdot 2\end{array}$ & $\begin{array}{l}97 \cdot 2(8) \\
47 \cdot 1 \\
43 \cdot 1\end{array}$ \\
\hline
\end{tabular}

L.S.D. 2 means of $8=3 \cdot 9$ at $P=0 \cdot 001$.
L.S.D. 2 means of $4=5 \cdot 6$ at $P=0 \cdot 001$.

$F$ test significance at $P=0.001$.

The difference in $\Delta \mathrm{NH}_{\mathbf{4}}-\mathrm{N}$ found by these two methods after anaerobic incubation is shown to be large for the humic ferrisol and is attributed to decomposition of organic matter with the formation of $\mathrm{NH}_{4}-\mathrm{N}$; high $\mathrm{NH}_{4}-\mathrm{N}$ values may be found for some soils at the end of the incubation period when steam distillation is carried out in the presence of the soil. It seems probable that this source of variation would account for the less satisfactory correlations shown in Table 1 between the anaerobically determined $\Delta$ mineral $-\mathrm{N}$ and the different soil and crop parameters.

An inspection of the data used in ealculating the correlation coefficient between the aerobic and anaerobic mineral- $\mathrm{N}$ values for the $1963 / 64$ field trial soils shown in Table 1 revealed a single discrepant soil; omitting this pair of figures a recalculated correlation coefficient of $r=0.682^{* *}$ with 17 d.f. was found. The lack of, or low, correlation between the $\Delta$ mineral-N figures (Table 1) by the two methods compared with the high degree of correlation reported by Waring and Bremner ${ }^{1}$ is attributed to the fact that they worked with soils of a similar type (black earth soils), whereas my samples were more variable and included eight distinct types developed over several different parent rock materials.

Subsequent experimentation has shown that the determination of $\mathrm{NH}_{\mathbf{4}}-\mathrm{N}$ in the anaerobic soil incubation method of Waring and Bremner ${ }^{\mathbf{1}}$ is more reliably carried out for certain soils by distillation of the $\mathrm{NH}_{1}-\mathrm{N}$ from a filtered extract, a modification which involves very little additional time and effort in this test.

\section{J. B. D. Robinson}

East African Agriculture and Forestry

Research Organization,

P.O. Box 30148,

Nairobi, Kenya.

Received November 29; revised December 19, 1966.

${ }^{2}$ Waring, S. A., and Bremner, J. M., Nature, 201, 951 (1964).

"Bremner, J. M., in Methods of Soil Analysis (edit. by Black, C. A., ot al.), 1241 (Amer. Soc. Agron., Madison, 1005).

${ }^{3}$ Russell, E. W., Soil Conditions and Plant Growth, eighth ed., 254 (Longmans Green, London, 1050).

- Bremner, J. M., Methods of Soil Analysis (edit. by Black, C. A., et al.), 1196 (Amer. Soc, Agron., Madison, 1965)

' D'Hoore, Soil Map of Africa. Explanatory Monograph. Joint Proj. No. 11, Comm. Tech. Co-op. in Africa, Lagos, 103, 107 (1964). 